Kamil Minkner*

\title{
Polish contemporary art to the anti-Semitism of Poles and its political significance
}

KEYWORDS: the political, art and politics, anti-Semitism, discourse symbolic stowa KLUCzowE: polityczność, sztuka a polityka, antysemityzm, dyskurs symboliczny

\section{An insight into the discourse of symbolic elites}

The purpose of these considerations is the analysis of Polish contemporary art, which is subject to the problem of Polish anti-Semitism. With specific regard, I discuss the works that relate - directly or indirectly - to the pogrom of Jews in Jedwabne on 10 July 1941. After 2000, when Neighbors by Jan Tomasz Gross was published, this issue became an important topic of public debate in Poland. In the text, I try to show that the artistic achievements are its essential part. For this reason, I see art as a part of the political discourse of symbolic elites, which describe, interpret or evaluate specific events. This plane includes the symbolic processing of real facts, which is associated with the creation, distortion, dissembling and falsification of the picture of social reality ${ }^{1}$. Symbolic elites do not apply to political power, but cultural and normative control over public discourse, which is expressed in prioritizing of important issues and moral and aesthetic values. With regard to these considerations, I consider that the product of this discourse is both the same artistic achievements, as well as public comments made to them by the senders and recipients in the ideological context. The ideology is not so much a single cognitive structure, but the resources provided by the culture of the argumentative possibilities or symbols that make sense only within a particular use and situation ${ }^{2}$.

* Ph. D. in political science, Department of Theory of Politics and Political Thought, Institute of Political Science, University of Opole. Mail: kminkner@uni.opole.pl.

1 P. Ciołkiewicz, Debata publiczna na temat mordu w Jedwabnem w kontekście przeobrażeń pamięci zbiorowej, „Przegląd Socjologiczny” 2003, nr LII/1, p. 288.

2 M. Czyżewski, S. Kowalski, A. Piotrowski (edit.), Rytualny chaos. Studium dyskursu publicznego, Kraków 1997, pp. 17, 25. 
In the literature, there are at least a few studies that discuss public debate about the pogrom in Jedwabne $e^{3}$. In political science considerations, it lacks the references to art. The following article wants to fill this gap. I mean not only the interpretation of the research material, but also its arrangement. On this basis, I would like to test the hypothesis that art relating to anti-Semitism in Poland is political, as it constitutes a challenge to the established and conventionalized historical memory. In this particular case, I would go about it, how art transforms the trauma of Polish anti-Semitism, becoming thus a tool of collective national psychotherapy. I understand the political dimension of the discussed art in two ways: as a mirror of certain tendencies throughout the issues touched upon by artists, and as an instrument in the public debate.

In my considerations, I hinge on two basic assumptions. First, I treat politics through the prism of the struggle for meaning in public space considering that what is political is associated with the symbolic actions: naming, defining, interpreting, disclosure. According to Zbyszko Melosik, „the struggle for meaning - imposing them as binding - is associated with the desire to legitimize society defined „versions of reality”, at the expense of the alternative version" ${ }^{4}$. Bearing in mind the problems of the text, I recognize the struggle for meaning in terms of "politics of symbols”. According to the researcher of ethnic conflicts in the Balkans, Ivan Čolović symbols in politics are not only a means to an end. „The biggest and richest kingdom, which politicians and generals, clerics and poets win with volleys of words, sermons and poems, is just the area of symbolism" ${ }^{5}$. Many political scientists still recognize that a key sphere for them is state authorities or competition of political parties. In this context, the concept of politics proves invigorating, so that it can be shown that the political can be expressed in the social, personal sphere, or, as I show in these deliberations, art. At the most fundamental level the political means for me the tension between the way of organizing a society, and lying in its bosom structural contradictions ${ }^{6}$. If political refers to the ontological level of society ${ }^{7}$, the problem of anti-Semitism in this sense, has the status of political, that discussing it can reveal fundamental social antagonisms.

Secondly, art as essentially a symbolic practice is not an autonomous field, but as part of the social sphere is a weapon in the debate and struggle whose stake is determining

3 The most comprehensive public discourse around the pogrom in Jedwabne is presented in: P. Forecki, Spór o Jedwabne: analiza debaty publicznej, Poznań 2008.

4 Z. Melosik, Poststrukturalizm jako teoria życia społecznego, „Kultura Współczesna” 1997, nr 1, pp. 111-112.

5 I. Čolović, Polityka symboli. Eseje o antropologii politycznej, Kraków 2001, p. 5.

6 I write more widely on this subject in: K. Minkner, Problem polityczności jako metateoretyczne wyzwanie dla politologii, „Athenaeum” 2014, nr 43, pp. 7-22; K. Minkner, Główne problemy konceptualizacji pojęcia polityczności, „Studia Politologiczne” 2015, vol. 37, pp. 50-74.

7 Chantal Mouffe describes the political in his book Polityczność, Warszawa 2008, p. 23. The author applies this concept to the way in which society is constituted. 
the current meanings, as well as negotiating or contesting the symbolic and social order. Jacques Rancière writes in this regard on the division of sensuality, in which it is essential to unfold of what was not visible. Policy manifests itself through specific aesthetic shape, but also the aesthetics or art are always political ${ }^{8}$. Regarding the problem of Polish anti-Semitism the fact of its disclosure in the context of the tensions related to its displacement proves the political of art. The strength, also political, of art is that it can extract what is invisible in the public debate, which traditionally is out of the picture frame or the frame of the film. Artur Żmijewski in his manifesto Applied Social Arts stated unequivocally that politics is the power of naming, and thus the art has enormous political power because it defines the elements of the social structure and interferes with the cultural order. According to Żmijewski, unlike science art does not have to take reality in parenthesis, but looks at society as if from the inside 9 .

The text discuss the first foundation of research that allows me to use reliably the concept of politics in relation to the artistic activity. Therefore, at the beginning I justified this theory that art is a form of historical memory. Based on these findings, I try to answer the question of what specific type of anti-Semitism worked troughed Polish art and I deal with psychoanalytical aspects of art to the trauma of the pogrom in Jedwabne. Throughout the text, I present as discussed works have inscribed in the debate conducted on the Polish anti-Semitism by the Poles themselves.

\section{Art as a form of historical (post) memory}

At a general level political dimension of art can be expressed through the prism of a specific form of political consciousness of social groups. I understand political consciousness, following Leszek Sobkowiak, the elements of subjectivity, which are associated with knowledge, assessments, emotions and patterns of political behavior ${ }^{10}$. Due to the fact that art is a symbolic activity I treat it as a separate type of knowledge, the advantage of which is reaching out to those dimensions of human life, which are so complex that they do not lend themselves to end the strict rigors of science based on facts ${ }^{11}$. I develop also my research on the political of film art, which I found among others that cinema is a symbolic mirror of socio-political developments, which is expressed in a variety of metaphorizing strategies through which artists sublimate real-

8 J. Rancière, Estetyka jako polityka, Warszawa 2007, p. 25.

9 A. Żmijewski, Stosowane sztuki społeczne, „Krytyka Polityczna” 2007, nr 11/12, p. 17 and 20.

10 L. Sobkowiak, Świadomość i socjalizacja polityczna [in:] Studia z teorii polityki, t. 1, A.W. Jabłoński, L. Sobkowiak (edit.), Wrocław 1999, pp. 157-158.

11 J. Such, M. Szcześniak, Filozofia nauki, Poznań 2000, p. 39. 
ity $^{12}$. In developing this thesis I claim that art as a particular manifestation of political awareness is expressed in symbolic, mythological, metaphorical, narrative forms, and so in a variety of representations of facts and phenomena.

The political dimension of art as a form of political consciousness can be understood subjectively and objectively - using the criteria of the political phenomena within the meaning of Mirosław Karwat. At the level of subjective art it can be recognized as an intentional aspect of the aspirations, needs, values, beliefs of certain political entities. We can find different situations, for example, when the entities consciously create, inspire, provoke, promote certain artistic activities, but also when they acclaim and sometimes even appropriate these activities. Objective plane of the political art is expressed through the entanglement of the work of the weave needs, goals and interests of different actors, as well as macro-social significance of this contradiction ${ }^{13}$. Both of these dimensions also could be seen in the context of working through the art of Polish pogrom in Jedwabne.

In this article I am interested in this dimension of political consciousness, which is associated with collective memory. As pointed out by Paul Race collective memory is important in the process of constructing national identity, acting on the duration of a given entity. The author also points out that many shots indicates that it is not a register that just passively collects facts, but subjects them to interpretive processing ${ }^{14}$. These properties of collective memory cause that it is often at stake in the ideological confrontation.

Output understanding of the collective memory I accept for Barbara Szacka, who defines this as ,ideas about the past of their own group, constructed by individuals with saved by them - according to the rules discovered by psychologists - information from various sources and coming to them through various channels. They are understood, selected and transformed according to their own standards of cultural beliefs and outlooks. These standards are produced socially, and therefore they are common to members of a given community, leading to the unification of ideas about the past, and thus this lets talk about collective memory of the history of their own group"15. Collective memory is in its terms a field of confrontation, the clash of different perspectives, as well as tensions between the official and colloquial versions. the political potential of collective memory expresses in the contradictions. For this purpose, Lech Rubisz extracts in its framework historical memory, which is defined as objectively

12 See wider: K. Minkner, O filmach politycznych. Między polityką, politycznościa i ideologia, Warszawa 2012.

13 I presnt the criteria of the politics of phenomena from: M. Karwat, Polityczność $i$ upolitycznienie. Metodologiczne ramy analizy, „Studia Politologiczne” 2010, Vol. 17, pp. 63-88.

14 P. Ścigaj, Tożsamość narodowa. Zarys problematyki, Kraków 2012, pp. 99-100; 179-185.

15 B. Szacka, Czas przeszły, pamięć, mit, Warszawa 2006, p. 44. 
existing political aspect of group consciousness because the story is largely a reconstruction of the political fate of the community and such or another understanding of its political fate shapes its identity. Rubisz also emphasizes that the historical memory consists of both the facts and the surrounding emotions and symbols and various subjective reconstructions, which may determine the conflict or consent ${ }^{16}$.

One of the varieties of historical memory, particularly important in the analysis of anti-Semitism is so-called post-memory. The author of this concept is Marianne Hirsch, who proposed this concept analyzing the works of writers and artists of the second generation after the Holocaust in the context of their autobiography. They did not survive the traumatic event directly, but experienced it through a variety of relationships with strong emotional charge, which meant that they became the foundation of their own memory. „Post-memory is therefore not connected with the past, which literally returns. It returns in the form of investment of ideas, different kinds of projections or artistic creativity" 17 . This symbolic and emotional dimension of the post-memory is not expressed through scientific findings, but especially through various symbolic representations, including art, which is of paramount importance in restoring the structures of social memory. According to Katarzyna Kaniowska post-memory is highly mediated form of collective memory; this kind of „narrative about the narrative” 18 .

The mechanism of the political of historical memory includes different levels: social (group identity, belief, political correctness, environmental pressures); socio-political (ideologies, inter-party rivalry); nationality (the international situation, raison d'état). Within the post-memory, various collective memories fight with each other ${ }^{19}$. There is also tension between memory and different forms of collective amnesia, meaning by Marian Golki „everything that is outside the social consciousness of the members of the group" 20 . Wherein the amnesia can be either the result of forgetfulness, but also, as in the case of Polish anti-Semitism, denial or even erasure, so the total disposal of traces.

In the text, I deal with the art that political power stems from the fact that it constitutes an instrument of the fight with the collective amnesia, which usually has a subversive significance from the point of view strongly conventionalized discourse around the Polish national identity. This discourse consists of a set of ideas formed by years

16 L. Rubisz, Polityczność historii. Uwagi teoretyczne i metodologiczne, „Athenaeum” 2014, nr 43 , pp. 31-32.

17 M. Hirsch, Pokolenie postpamięci, „Didaskalia” 2011, październik, nr 105, p. 29.

18 K. Kaniowska, „Memoria” " „postpamięć” a antropologiczne badanie wspólnoty [in:] Codzienne i niecodzienne. O wspólnotowości w realiach dzisiejszej Łodzi, G.E. Karpińska (edit.), „Łódzkie Studia Etnograficzne", vol. 43, Łódź 2004, pp. 9-28.

19 L. Rubisz, Polityczność historii..., p. 32.

20 M. Golka, Społeczna niepamięć: pomiędzy zapominaniem a zamazywaniem [in:] Pamięć, przestrzeń, tożsamość, S. Kapralski (edit.), Warszawa 2010, p. 54. 
of annexation, as well as fighting for independence. These ideas were articulated most perhaps in the romantic program of Adam Mickiewicz. National identity merged in his works with religious identity, often even with messianism, which was expressed through the celebration of the victims and defeats that ennobled the nation. Art reproduced this syndrome, but also allowed to disclose it. According to Maria Janion, Norwid, Gombrowicz and Miłosz criticized Mickiewicz, that he had contributed to the recognition of nationality as exclusivity, as the absolute, which is associated with Christ's innocence at the same time ${ }^{21}$. In that discourse a Jew is a figure of a stranger who disrupts the essence of Polishness.

\section{Post-Jedwabne art as a platform of the debate on Polish anti-Semitism}

In the following part of the text, I would like to get into the arts, for which I accept contractual term "post-Jedwabne art". Despite its name, it is not just about the works that subject to murder in Jedwabne. This creative output also includes works of art that are part of the broader debate on the Polish anti-Semitism, which was initiated thanks to the publication of the book Neighbors by Jan Tomasz Gross. On the other hand, even those artists who, like Zofia Lipecka, simply use the name Jedwabne set themselves more universal targets. Lipecka in her video work about the pogrom says that she is interested in how much in a man is what is inhumane, and also an attempt to reflect on the essence of genocide ${ }^{22}$. It should be emphatically pointed out that the proposed in the text the analytical aspects of these works do not exhaust their artistic and therefore interpretative wealth, and the intentions of the creators of these works can not be reduced to emergency willingness to participate in the public debate.

In the case of working through the pogrom in Jedwabne, art has been present from the very beginning. Even before Gross's book, in 1999, a documentary film by Agnieszka Arnold ... Where's my older son Cain was broadcast by Polish TV. The film showed multi-faceted Polish-Jewish relations during the Second World War, however, without causing any unrestrained social response. The author spoke with both ordinary Poles and Jews, who emigrated, as well as with such prominent figures as Jan Karski. In this panorama of different opinions, she revealed a complex picture of Poles who had helped Jews alike, and had been passive in relation to their persecutions. This was the first time when the wider public learned about facts of the mass murder in Jedwabne.

21 M. Janion, Trudna klasa w ciężkiej szkole, preface to: J. Tokarska-Bakir, Rzeczy mgliste. Eseje i studia, Sejny 2004, pp. 6-7.

22 Zofia Lipecka „Po Jedwabnem”, source: http://culture.pl/pl/wydarzenie/zofia-lipecka-pojedwabnem [access: 12.07.2015]. 
In the film, this is only a short piece but bears the source witness in the form of witness testimony of Szmul Wasersztajn who survived the pogrom. The author of the film continued her search on the topic and in 2001 her film Neighbors was released. It is with her consent that Gross thus entitled his book and used the expressions of characters from the director's film ${ }^{23}$.

The reaction to Gross's book formed part of the criteria of other ideological disputes in Poland from the beginning. The most important conclusion from the provoked by the book debate on the Jedwabne massacre is that in the course of discussions intermediate courts lost, even historian Tomasz Szarota's, who considered the book as shocking, emphasizing indisputability of the main facts. However, he accused the author of Neighbors of rush in the evaluation and selection of sources. It made him think that Gross at all ruled out any German participation in the pogrom ${ }^{24}$. Not taking into account this type of opinions was associated with a strong polarization of positions on the theses posed by Gross and within individual camps the extreme and expressive positions supported by the choice of experts were highlighted. On the one hand, they considered full responsibility of the Polish nation and the full support of Gross's coclusions. On the other hand, they argued that the Poles were not at all responsible for the pogrom, a position that was supported by representatives of the Catholic-nationalist circles. They claimed primarily on the historian Tomasz Strzembosz's assertion, according to which Germans were not only the organizers of the massacre in Jedwabne, but even they killed the Jews. The polarity of positions led to the so-called. ritual chaos when it comes to social impression that the agreement in the debate is fundamentally impossible because the parties are focused on uncompromising articulating their views in the framework of the dichotomy of the we-they order ${ }^{25}$. This type of logic is activated in relation to the events, „the interpretation of which is part of the game to change or maintain the current balance of political forces" ${ }^{26}$. These positions were then shifted to the evaluation of artistic activities, which can prove that art could not overcome the effect of the ritual chaos. An example might be a dispute about Ida by Paweł Pawlikowski which appeared between the national and the Catholic right and the left. In this context, opinions of the critics who, like Tadeusz Sobolewski, recognized that

23 P. Forecki, Spór o Jedwabne..., pp. 14-16.

24 Diabelskie szczegóty, Jacka Żakowski’s converstion with Tomasz Szarota, „Gazeta Wyborcza" on 18-19 November 2000, pp. 10-12.

25 The authors who write about that in the context of Jedwabne: M. Bilewicz, Wyjaśnianie Jedwabnego: antysemityzm i postrzeganie trudnej przeszłości [in:] Antysemityzm w Polsce i na Ukrainie. Raport zbadań, I. Krzemiński (edit.), Warszawa 2004, pp. 257-260; P. Ciołkiewicz, Debata publiczna na temat mordu w Jedwabnem..., p. 297. About the ritual chaos see: M. Czyżewski, W strone teorii dyskursu publicznego [in:] Rytualny chaos..., p. 53.

26 Preface to co-work: Odmiany dyskursu politycznego, P. Woroniecki (edit.), Olsztyn 2007, p. 13. 
Ida is a movie rising with its artistic form above political divisions turned out to be isolated. Sobolewski criticized the ideological dispute, which was fought around the film by both full-of-fears fundamentalists ${ }^{27}$, as well as some representatives of the left (eg. Agnieszka Graff) spotting in the film anti-Semitic clichés (duplication of the stereotype of Jews who collaborated with the Communists ${ }^{28}$.

All the works commenting on the massacre in Jedwabne can be included into the socalled 'main arena' of the dispute, within which the participation of Poles in a pogrom is called into question ${ }^{29}$. While historians even in this arena had different views on the role of the Germans or Gross's methodological accuracy, artists spoke more forcefully arguing that the responsibility of Poles was associated with their anti-Semitism. Some critics even pointed that these had too ad hoc and instrumental character. Dariusz Nowacki referring to the drama Mykwa by Piotr Rowicki (and to a lesser extent, Nasza Klasa by Tadeusz Słobodzianek) wrote that the plays were not inconvertible, i.e. that de facto they can be replaced by journalism ${ }^{30}$. Most of the analyzed works that relate to the massacre of Jews in Jedwabne and Polish anti-Semitism can be considered as part of the discourse which Piotr Forecki defines as moral. Its essence is self-critical transfer of responsibility to the entire Polish national community in order to obtain a kind of ethical self-reflection of Poles on themselves ${ }^{31}$. This arrangement is part of the rules of the ritual of chaos, where the moral rightness dominates the instrumental effectiveness ${ }^{32}$. As a result, the public is completely confused.

As Michał Bilewicz proves commenting on social research from the year 2002 on the assessment of Poles of the events in Jedwabne there was a very high level of ignorance of what really happened. Almost $25 \%$ of people undermined the very fact of the pogrom. Psychologically these studies revealed the so-called ultimate attribution error functioning in Polish society. This translates to the effect that all the negative deeds of the Jews result from their hatred towards Poland; all the negative deeds of Poles result from the fact of the German occupation. These findings support the general conclusion that in the case of Jedwabne there was only a "ritual of reconciliation”, which na-

27 One of the right-wing organizations Redoubt of Good Name - Polish League against Defamation (Reduta Dobrego Imienia - Polska Liga przeciw Zniesławieniom prepared an online petition addressed to the Polish Film Institute, asking to place information before the film, which was to explain the fact that Poland was occupied by the Germans during the war, and they prepared the extermination of the Jews. See: P.T. Felis, „Ida” antypolska?, „Gazeta Wyborcza” on 22 January 2015, p. 1 .

28 T. Sobolewski, Światopogladowe zasieki, „Gazeta Wyborcza” on 14 November 2013, p. 15.

29 P. Ciołkiewicz, Debata publiczna na temat mordu w Jedwabnem..., p. 295.

30 D. Nowacki, Robota ilustracyjna i wychowawcza, „Teatr” 2008, nr 12, pp. 8-11.

31 P. Forecki, Spór o Jedwabne..., pp. 29-30.

32 M. Czyżewski, S. Kowalski, A. Piotrowski (edit.), Rytualny chaos..., p. 31. 
tional celebrations were an expression of; whereas the society was not ready for such reconciliation ${ }^{33}$.

Artists themselves set the goal to change this. And probably because of it they needed time to look at the problem from a distance. Artistic working through the traumas associated with the pogrom in Jedwabne and Polish anti-Semitism did not begin on a large scale until several years after the end of the media debate and it covered all major areas of artistic activities: non-fiction (reports My z Jedwabnego by Anna Bikont, 2004; Oskarżam Auschwitz. Opowieści rodzinne - collection of interviews by Mikołaj Grynberg, 2014); fiction (Asystent śmierci by Bronisław Świderski 2007; Pingpongista by Józef Hen, 2008; Noc żywych Żydów by Igor Ostachowicz, 2012), drama (Nasza klasa by Tadeusz Słobodzianek, 2008; Żyd by Artur Pałyga, 2008; Mykwa by Piotr Rowicki, $2008^{34}$ ); artistic film (Ida by Paweł Pawlikowski, 2013); avant-garde cinema (Mary Koszmary by Yael Bartany, 2007); mainstream films with more commercial potential (e.g. Pokłosie by Władysław Pasikowski, 2012), documentaries (Sasiedzi by Agnieszka Arnold, 2001); copyright video works having the character of ethnographic registration (Polak w szafie Artura Żmijewskiego, 2007), painting (Chaim Goldberg's works; Antysemityzm wyparty by Kamil Kuskowski), modern visual art (video installations and photographic works by Zofia Lipecka). Performance actions must be mentioned as well (Płonie stodoła by Rafał Betlejewski; Pływalnia by Rafał Jakubowicz), permanent interventions in urban space (Pozdrowienia z Alej Jerozolimskich by Joanna Rajkowska, 2002), murals (fragments of comic Maus. Opowieść ocalałego by Art Spiegelman used by Wilhelm Sasnal, 2002).

It is difficult to estimate the degree of representativeness of these artistic expressions of the entire Polish art after 2000. This comparative statistics, however, is unnecessary. Examples Pokłosie, and to a lesser extent, Nasza klasa or the action Płonie stodoła clearly show that sometimes a single work is able to elicit a lively debate breaking the dominant trends. On the other hand, the amount and quality of artistic achievements regarding anti-Semitism after the release of Gross' book compared to the previous period can decisively conclude that we are dealing with the significant phenomenon.

A key political aspect of a settlement by the Polish art of anti-Semitism is a revision of Polish collective memory, especially the historical one, and at the same time national identity. The different artistic activities are thus the gesture of revealing lurking beneath the surface social antagonisms within Polish society (eg. Pokłosie by W. Pasikowski, Nasza klasa by T. Słobodzianek). Some works relate to anti-Semitism in general, searching for a more universal perspective. This type of proposal is fleeing

33 See wider: M. Bilewicz, Wyjaśnianie Jedwabnego..., pp. 255-263.

34 The specified dates indicate the moment of the creation of the literary version of these dramas, and not the stage versions. 
from the literal Asystent śmierci by Bronisław Świderski, who tell with a method of stream of consciousness about a Polish intellectual (the author himself), who after writing an article about Søren Kierkegaard's anti-Semitism is released from the academic institution. The author applied numerous formal measures balancing between autobiography and fiction, as well as prose, verse and drama. In the film, an attempt to move away from journalism for universal history was Ida by Paweł Pawlikowski. $Z$ daleka widok jest piękny (2011) by Anka and Wilhelm Sasnal even more generalized the problems.In the film neighborly relations not only concern the Poles and the Jews, but they become a metaphor for social relations in the Polish countryside, and perhaps even relationship of closeness marked by tensions and contradictions. References to Jedwabne, however, were still visible as a journalist of "Gazeta Wyborcza" Donata Subbotko claimed that was a film "about the Jews without Jews. There is looting, setting fire to the house, the river, which we know that during the war the corpses were floating in it - "but it were not the Poles", says one of the peasants" 35 . In the theater Artur Pałyga's play $\dot{Z} y d$ directed by Robert Talarczyk undertook an attempt of cross-cutting revision. Yoy can seethere the school board meeting in the Polish school, which discusses the matter of their former pupil, now a famous Jewish writer. His son wants to find old school father's work. Teachers use this as an opportunity to take advantage of Jewish money to rescue the financially failing schools and offer even to call the school name of the writer. At the same time reveal numerous phobias in relation to the Jews, and what is worse, ignorance and repressed guilt. Suffice it to mention that the school principal is a person who has obtained his social status thanks to the events of March 1968. As a critic Lukasz Drewniak deftly summed up the play in his review, 'director Robert Talarczyk unleashes "seance total hatred". Not against the Jews, or even Jeweaters. This session hatred for hatred"36.

In addition to the settlements, direct references to Jedwabne always causing lively debate appeared in the general tone. Depending on the type of artistic medium the debates closed either in the circle of symbolic elites or penetrated to the wider public by calling a broad social response. The first case relates primarily to the visual arts and theater, and a particular example proved a drama Nasza klasa by Tadeusz Słobodzianek directed by Ondrej Spišák 2010 in Theatre in Wola (the scene of Dramatic Theatre in Warsaw).

Creators of Nasza klasa do not use the name of Jedwabne, although the references are clear. The play reveals the causes, course and post-war blurring the memory of the

35 Dzisiaj omijam zawiść, D. Subbotko's interview with a painter z W. Sasnal, „Gazeta Wyborcza” on. 9 February 2012, „Duży Format”, p. 2.

36 Ł. Drewniak, Seans nienawiści, źródło: http://www.teatr.bielsko.biala.pl/s/seans-nienawisci. html [access: 21.07.2015]. 
pogrom, but the artists are all the time trying to run away from literalism to speak about the moral condition of a man. According to the director Nasza klasa is the "universal history, understood wherever there are deep ethnic conflicts and private life must give way to big politics. It is important to us that this was the story of the people that we meet on the street and with whom the audience can identify with" ${ }^{37}$. The play therefore proposes a private prospect of though at the same time proves that what private is politically involved. Słobodzianek and Spišák do not give a definite answer to how antagonism was born. „The fate of the heroes of the drama, which the actors play on the stage where the school benches are the only decoration, is the result of the action of both the ruling ideology, history, and education, personal abilities, ambition, disappointed or fulfilled love, hate, revenge, fear. No one is born a monster, no one is an innocent victim. The roles in following sequences show a turn with a rotating wheel of history"38. It should be added that Nasza klasa formed part of a wider debate on Polish settlements with the small and great history, referring even polemically to Umarła klasa by Tadeusz Kantor. This was pointed out by a literature historian Leonard Neuger, who wrote that in Kantor's 'colleagues' ghosts, victims of the Holocaust, are a signal of irretrievable loss. In Słobodzianek's play it is vice versa - these are the ghosts that most we would like to get rid of. The loss would be a blessing that we have been denied"39.

The transmission on TVP Kultura with the debate after the broadcast with the participation of Tadeusz Słobodzianek, Aleksander Smolar (President of the Stefan Batory Foundation) and the right-wing journalist Maciej Pawlicki can provide the importance of Nasza klasa. While Smolar supported the vision of the director, Pawlicki criticized it and said that such art will contribute to the development of anti-Semitism in Poland. This is consistent with the logic of reasoning of other right-wing columnists. Rafał Ziemkiewicz said on one of the anniversary of the pogrom in Jedwabne, that stigmatization of anti-Semitism supports the environment of „Gazeta Wyborcza”, which feeds on this kind of accusations to antagonize Poles, criticize Catholicism and tradition. „For the average Pole - without going into detail - „the Jews” should be blamed for the lie about Jedwabne. And their reaction of awakened by this lie resentment is guided against the Jews" ${ }^{\prime \prime}$.

37 Ondrej Spišáko „Naszej klasie”, source: http://teatrdramatyczny.pl/index.php?option=com_ content \&view $=$ article \&id $=851$ :ondrej-spiak-o-qnaszej-klasieq \&catid=65\&Itemid $=251$ [access: 12.07.2015].

38 A. Kyzioł, My z naszej klasy, „Polityka”, 30 October 2010, source: http://www.polityka.pl/ tygodnikpolityka/kultura/teatr/1509844,1,recenzja-spektaklu-nasza-klasa-rez-ondrej-spisak.read [access: 14.07.2015].

39 Tadeusz Słobodzianek, „Nasza klasa”, source: http://culture.pl/pl/dzielo/tadeusz-slobodzianek-nasza-klasa [access: 12.12.2015].

40 R.A. Ziemkiewicz, Jedwabne, czyli zaduch kłamstwa, „Do rzeczy”, 13 lipca 2013, source: http://dorzeczy.pl/id,1095/Jedwabne-czyli-zaduch-klamstwa.html [access:11.07.2015]. 
Direct settlement of the pogrom in Jedwabne was also made in the context of art with more commercial potential, with all the arbitrariness of this type of separation. This is primarily about the film works, which a relatively large group of customers took note of. The most spectacular achievement was in this regard aftermath Pokłosie by Wladysław Pasikowski which only in the cinemas was watched by just over 300,000 viewers in the premiere $(2012)^{41}$. The film shows in a thriller convention how hard it is to break through the conspiracy of silence against, displaced by years, guilt of murdering Jews by their Polish neighbors. The film was also one of the most media bearing. Some right-wing critics argued that it is anti-Polish character and is more dangerous than Gross's Neighbors as it indicates the Poles as a sole perpetrators of the crime. When playing in it Maciej Stuhr said that the Poles can not talk about the bad sides of their history and gave a false example of tying Polkaów children in Cedynia by Poles he met with a wave of hatred on the Internet (so-called Hejt). He was accused, among others, that he is a non-Polish actor, a traitor, or even representative of Jew-commune ${ }^{42}$.

As far as what happened in Jedwabne during the war has become a symbol of stories about mutual relations between Poles and Jews, so much a symbol of the event became a barn in which that cruel murder was committed. It is also used in some artistic activities. An example might be artistic action performer Rafal Betlejewski. On 11 July 2010 in the village Zawada near Tomaszów Mazowiecki, he burned a barn along with small cards, which symbolized unkind thoughts toward Jews. In the reportage, which documents this action author stresses that Gross's Neighbors was a shock. Then he rated himself as a Polish ignoramus who knew nothing about the Holocaust of the Jews and of Polish anti-Semitism. In his view, the action was to symbolize the transition from the outside of the barn, symbolizing the role of executioner, to the inside, and so a symbolic contributor who takes the side of victims. The action was assessed as extremely controversial. Even the Jewish community in Poland, such as Polish Jews Forum, protested. The performer was accused of too clear and easy interaction. Regardless of the assessment, the author was able to show the political dimension of historic symbols, and mainstream media widely reported about his performance ${ }^{43}$.

Works from the analyzed topic create an interesting group, which can be described collectively as inclusive. Their political potential is expressed not only in the revision

41 Information about the number of spectators from Polish Film Institute (Polski Instytut Sztuki Filmowej). Source: https://www.pisf.pl/rynek-filmowy/rynek-filmowy/widzowie [access: 23.11.2015].

42 The public debate about film Pokłosie is commented by: P. Forecki, Pokłosie, poGrossie i kibice polskości, „Studia Litteraria et Historica” (SLH) 2013, nr 2, pp. 211-235.

43 You can watch the reportage from the performance on YouTube: https://www.youtube. $\mathrm{com} /$ watch? $\mathrm{v}=\mathrm{r} 21$ Jur404Lo [access: 12.07.2015]. Among others TVN infromed about it, see: Płonie stodoła. Na pamiątkę pogromu Żydów, source: http://www.tvn24.pl/wiadomosci-z-kraju,3/ploniestodola-na-pamiatke-pogromu-zydow,139672.html [access: 16.07.2015]. 
of historical memory, but new ideas for integration of Poles and Jews. These are all the activities that appeal affirmatively to a common Polish-Jewish past through artistic actions, while striving after reconciliation or better understanding between the two nations at least in an imagined way. This art can provoke a debate on anti-Semitism, but also goes beyond that area.

One of the best examples of the inclusive trend is triptych video, which was shown in 2011 at the Venice Biennale under the collective name ... and Europe will be stunned (...i zadziwi sie Europa). Its author, Yael Bartana was the first person from abroad, who represented Poland at the event. The project consisted of three separate works: Mary Koszmary (2007), Mur i wieża (2009), Zamach (2011). Breaking with the autonomy of art the author set a target to produce through artistic activities also political implications. Her subsequent short films tell the story of the Jewish Renaissance Movement in Poland, whose foundations the author really wanted to create. In the first work disguised as a communist apparatchik Sławomir Sierakowski speaks at the empty, then still existing 10-Anniversary Stadium, and the whole is maintained in the spirit of propaganda chronicles. The content of the speech is an appeal, a call to the three million Polish Jews to return to Poland. There are also direct references to the expulsion of Jews from Poland and repentance, that this policy led to self-destruction and lack of orientation. Return of the Jews is to cause that no longer there will be suffering rivalry between nations. Get back not as the shadows of the past, but hope for the future. Welcome. No response to these words and empty stands of the stadium is a bitter response to this call. In Mur $i$ wieża we observe how the idea of integration is put into practice by the construction of the wooden kibbutz that is built by young Jewish activists in Muranów in Warsaw. An element of the whole is a tall wooden tower, on which a flag with the Polish eagle entered in the Star of David is posted at the end of the film. In the last part of the triptych, referring now to the future the leader of the movement is killed, but this sacrifice saves all the integration action. The intention of the author of the whole project is conceived as an "experimental form of group psychotherapy, where national demons are stirred and dragged into the light. Apart from the complex picture of Polish-Jewish relations, it is a universal story about the readiness to accept the other and cultural integration in an unstable world in the times of political revolts" 44 . As pointed out by Piotr Kosiewski of „Tygodnik Powszechny” in relation to the first part of the triptych Bartany project is an example of art looking for the right form to the Polish-Jewish dialogue. On the one hand, it is an excess, trespassing because the fall

44 Y. Bartana, ... I zadziwi się Europa, Press release prepared and published by the Warsaw Zacheta and signed with the seal of the Jewish Renaissance Movement. The note was issued in connection with the display of the work of Y. Bartany at the International Art Exhibition in Venice in 2011, p. 5 . 
because words unspoken so far are used. On the other hand, the use of the aesthetics of propaganda causes mistrust and takes the whole thing in quotes ${ }^{45}$.

Another interesting example of inclusive artistic activities is Rafał Jakubowicz's action Pływalnia (2003). Using high-power projectors the author displayed an inscription "swimming" in Hebrew on the building of the municipal swimming pool, which before the war had been a synagogue. The projection was watched the passers-by, and after the action a postcard was made, one side of which presented the image of the synagogue / swimming pool during the projection, and the other boys swimming in the pool. According to Eleonora Jedlińska, the light inscription "suggests a desire that this evening the wall would speak, the public swimming pool would become a monument of fragments of history pushed into oblivion" 46 .

\section{Types of anti-Semitism}

The political importance of working through anti-Semitism by Polish art now needs to answer the question of what kind of anti-Semitism we have to deal with. Sometimes, the dispute concerns the definition of anti-Semitism. This is the political significance because it involves a dispute about the effective way to interpret social reality. Art joins this defining as well, as exemplified in the work Śpiewnik prawdziwego Polaka by Katarzyna Kucharska (2014). The inspiration for this particular artistic action was discontinuance of the case of anti-Semitic chants at the stadium of Lech Poznan among which were cries of “Get out the Jews! Your home is Auschwitz! To gas!”. The author decided to collect this type of songs in one volume and she presented them in a plastic bag in which police publish crime scene evidence. Kucharska with her work drew attention to this aspect of anti-Semitism, which Halina Bortnowska defined as a legal opinion. In this context, some milieus, for example, use the term "Jews are weeds", considering that it is a metaphor ${ }^{47}$. The Court in Poznan applied such reasoning rec-

45 P. Kosiewski, Żydzi! Wracajcie!, „Tygodnik Powszechny”, 27 February 2008, source: http:// tygodnik.onet.pl/zydzi-wracajcie/tnsm5 [access: 15.07.2015].

46 E. Jedlińska, Rafał Jakubowicz - Synagoga/Ptywalnia, „Pro Memoria”, Biuletyn Informacyjny Państwowego Muzeum Auschwitz-Birkenau Fundacji Pamięci Ofiar Obozu Zagłady Auschwitz-Birkenau, 2007, nr 27, p. 94.

47 Antysemityzm jako taki, Przemysław Wiszniewski talks with Halina Bortnowska, source: http://www.otwarta.org/halina-bortnowska-antysemityzm-jako-taki/ [access: 10.05.2015]. The interview is on the website of organization "Open Republic” Association Against Anti-Semitism And Xenophobia („Otwarta Rzeczpospolita” Stowarzyszenie Przeciwko Antysemityzmowi i Ksenofobii). 
ognizing that chanted slogans were not addressed to the Jews, and so they sould not be taken literally ${ }^{48}$.

Researches on Anti-Semitism distinguish its different types. Studying the phenomenon since the beginning of the 90s Ireneusz Krzeminski and his team has distinguished two main types: modern anti-Semitism as an ideology and a traditional, religiously motivated one (accusing Jews of murdering Jesus) ${ }^{49}$. In the first case, anti-Semitism has ideological character because it turns to be a cognitive structure, which relatively comprehensively allows individuals and groups to define and interpret social reality. According to Krzemiński the views are based on three elements: the Jews rule the finances, seek to hidden power (over the world) and always stick together. In Daniel Pipes's opinion, a contemporary ideological anti-Semitism moves aversion from religion to race. It is based not on a particular fear, but an irrational fear. It goes from a simple prejudice to a kind of way of life and, in some cases leads to a permanent persecution of Jews ${ }^{50}$. What is important the Polish realities show that real Jews are not even needed for the existence of this type of anti-Semitism. In the case of post-war Poland Jew is primarily symbolic, is a figure of a Stranger threatening Polishness ${ }^{51}$. According to Slavoj Žižek anti-Semitism „treats Jewishness as a Thing that comes from the outside into the social body and disrupts its balance. [...] In the class struggle, classes lie in the antagonism, which belongs to the same social structure. In turn, for an anti-Semitic a Jew is an intruder from the outside, and it creates this antagonism" 52 . It is about ideas, passed down from generation to generation, and at the same time strongly marked in a conspiratorial way, which refers, among others, to the thesis that Jews have a tendency to dominate and influence in the world.

In this context, you can understand better delusional attacks on theater director Jan Klata even when the play created or promoted by him did not refer at all to the Jewish issue ${ }^{53}$ either to Mikołaj Grynberg, by the fact of touching on the subject of the

48 The description of Katarzyna Kucharska's work in a wider legal context is placed by the author herself on the website: http://borderlandsofartand.blogspot.com/2014/06/spiewnik-prawdziwego-polaka.html [access: 14.06.2015].

49 I. Krzemiński, Postawy antysemickie po dziesięciu latach i ich wyznaczniki [w:] Antysemityzm w Polsce..., pp. 15-78.

50 D. Pipes, Potęga spisku. Wpływ paranoicznego myślenia na dzieje ludzkości, Warszawa 1997, p. 46.

51 See among others: I. Krzemiński, Polacy i Żydzi - wizja wzajemnych stosunków, tożsamość narodowa $i$ antysemityzm [in:] Trudne sąsiedztwa. Z socjologii konfliktów narodowościowych, A. Jasińska-Kania (edit.), Warszawa 2001, pp. 173-174.

52 S. Žižek, Lacan, Warszawa 2008, p. 91.

53 See: Klata po protestach w Starym Teatrze: Można przeczytać, że jestem Żydem, pedałem, porno-Klatą. Aktorzy dostają listy z pogróżkami, source: http://m.wiadomosci.gazeta.pl/wiadomosci /1,117915,15015109,Klata_po_protestach_w_Starym_Teatrze__Mozna_przeczytac_.html [dostęp: 20.07.2015]. The article concerned the protests of audience at the Stary Teatr in Krakow, whenduring directed by John Klata performance To Damascus a scene of copulation appears. Under article 
Holocaust ${ }^{54}$. The negative formulations expressed in relation to them on online forums are also a kind of imaginary code that defines the identity of the group. It has to do with Ireneusz Krzeminski's conclusions of 2002, indicating that modern anti-Semitism can be seen through the prism of conventionally defined Polish national identity. According to Tomasz Żukowski from the Institute of Literary Research PAN Poles can not cope without Jews. „Hence the compulsion to confirm the superiority and reminder of it, as if without this our collective identity had to fly apart"55.

While the various aspects of modern anti-Semitism manifest themselves with the assessments of art expressed especially in conditions of relative anonymity of online forums, so much art itself worked through the variant marginally. Artists are primarily concerned with the so-called secondary anti-Semitism ${ }^{56}$. Michał Bilewicz, Marta Marchlewska, Nicholas Winiewski and Victor Soral suggested conceptualization of the issue. Within this concept there is denying his/her own anti-Semitism, blaming Jews for responsibility for the fate that met them, downgrading or denial of the Holocaust, cutting off from their own national past and the responsibility for the harm caused to Jews $^{57}$. The political importance of the secondary anti-Semitism is closely linked with the revision of the historical memory of Polish society and the sincere desire to reveal

there are128 entries on the forum of which a dozen directly expresses the various stereotypes about Jews, including keeping together and desire to dominate and the desire to influence.

54 It is the book by Mikołaj Grynberg Oskarżam Auschwitz. Opowieści rodzinne, which contains interviews with Holocaust survivors, now living in different countries. In an open letter to the editor of "Gazeta Wyborcza" the author lamented that under the interviews with him, which had appeared on the Internet and had been to promote the book, a huge number of entries explicitly anti- Semitic appeared. The author was ordered to leave the country, the Jews were accused that they did not want to assimilate, they were blamed for Polish suffering, accused of hatred of the Poles, and sometimes only insulted. See: „Siegnałem do komentarzy pod dwoma tekstami. Znalazłem morze agresji”, list Mikołaja Grynberga do redakcji „Gazety Wyborczej”, source: http://wiadomosci.gazeta.pl/wiadomosci/1,126753,17889872,_Siegnalem_do_komentarzy_pod_dwoma_tekstami_Znalazlem.html\#MTstream [access: 17.06.2015].

55 T. Żukowski, Nowa krytyczna pamięć, źródło: http://www.krytykapolityczna.pl/en/ksiazki/ksiazki-poza-seriami/20130710/przekroj-nowa-krytyczna-pamiec [access: 23.07.2015]. The text apeared primarily in weekly „Przekrój” (16 April 2012) and is an analysis of the book Festung Warschau by Elżbieta Janicka.

56 In the public debate, these trends are distributed more proportionally. Sergius Kowalski and Magdalena Tulli showed how in the large extent anti-Semitism manifests itself in the Polish public debate by analyzing various right-wing magazines. Seven out of ten registered hate speech applies to Jews. Conspiratorial themes appeared in these statements very often, because in $37.6 \%$. In the case of issues interesting to us as an example, you can take the text by Stanislaw Michałkiewicz on the head of Zachęta, Anda Rottenberg. The author says in it that „Jewish clique” gives away the posits in cultural institutions and the key criterion is the origin. On the other hand, different manifestations of secondary anti-Semitism often appeared, which is an essential component to deny antiSemitism alone (24.2\%). See wider: S. Kowalski, M. Tulli, Zamiast procesu. Raport o mowie nienawiści, Warszawa 2003, pp. 162; 484 and following.

57 M. Bilewicz, M. Marchlewska, W. Soral, M. Winiewski, Mowa nienawiści. Raport z badań sondażowych, Warszawa 2014, pp. 36-37. 
and discharge traumas. Artists including in the debate about Polish anti-Semitism want to restore only the subject, which in their opinion was ousted. Wherein in this respect it is the beginning of the book Noc żywych Żydów by Igor Ostachowicz: We do not contemplate our own misfortunes, so we do not have to remember them when we sweeten tea to our children ${ }^{58}$. The theme of fight with the denial of anti-Semitism also is subject to the series of paintings by Kamil Kuskowski Antysemityzm wyparty. The artist presented almost white canvas on which barely visible subtitles shine - like blurred slogans on the walls. These include "Jude Raus" with a swastika in the middle.

In all the analyzed works at least one of the separate elements of the syndrome secondary anti-Semitism appears. In some of them, for example, Nasza klasa or Pokłosie is almost all the components are present. In the case of the Pokłosie a good confirmation of the above claims may also be reviewing Internet forums (eg. On the film portal Filmweb, tab Pokłosie), where there are many entries accusing Jews of manipulating history, and sometimes also for crimes against the Poles.

An interesting dimension of working through of anti-Semitism in the art is the traditional variety. These references are, however, incomparably fewer, and artistic reflections on the kind of anti-Semitism have not gone beyond artistic niches. We should, however, keep in mind the data from the Polish Survey of Prejudice in 2013, which shows that the importance of the traditional anti-Semitism is growing, which in this study expresses in the belief that the Jews performed ritual murders, kidnapping Christian children, etc. Compared to 2009, when such beliefs were expressed by $15 \%$ of Poles, in 2013 their number increased to $23 \%{ }^{59}$. Perhaps the most important artistic project that has touched on this issue is Polak $w$ szafie by Artur Żmijewski.

This work presents a discussion and workshop work with the students, who in 2005 under the patronage of prof. J. Tokarska-Bakir collected statements of various people living in Sandomierz on the pictures of Charles de Prevot hanging in local temples. They showed ritual murder that Jews made to Christians. During the study, they found that the belief in ritual murders and abducting children for matzah appeared in every second interview. Nice, offering tea and biscuits people after beginning the Jewish subjects became suspicious and eventually unwilling and closed. Moreover, as Tokarska-Bakir emphasized, these ideas survived in all circulations: the elite, the socalled simple people, priests, teachers, etc. In her view, these views proved to be an effective diagram explaining why the Poles shortly after World War II robbed and murdered local Jews ${ }^{60}$.

58 I. Ostachowicz, Noc żywych Żydów, Warszawa 2012, p. 7.

59 M. Bilewicz, W. Soral, M. Winiewski, Antisemitism in Poland 2013: Research Report based on Polish Prejudice Survey II, Centrum Badań nad Uprzedzeniami, Warszawa 2013, p. 3.

60 Malarz tylko psa wymyślit, Anna Bikont: An interview with Joanna Tokarska-Bakir, „Gazeta Wyborcza" on 22 November 2008, p. 25. 
Anti-Semitism of nice and quiet every day people traumatized the researcher and her students, which required working trough. This is what Artur Żmijewski did in his film. In this sense, this work is a kind of treatment in relation to the uncomfortable truth showing yet universal mechanism of this process, which can be used in different social situations. The artist employed the technique of active workshops during which students could carry a token discharge on the replica of anti-Semitic picture. This was expressed by cutting, painting over, hiding, piercing, jerks, tan, puncture, and drawing a comic book, which was to show what really happened.

In the discussion arount the film, which Stefan Batory Foundation organized, the research tutor found that Żmijewski's film is important because art is more important in working through of uncomfortable truth than conventional education. The same truth is no longer enough; we need more provocative activities, which also have the educational significance. On the other hand, Zbigniew Nosowski, editor-in-chief of the monthly „Więź" found that the studies are indeed very important because they shows a problem that is not perceived but he criticized Żmijewski's film for glitches, especially a selective approach. In his view, this work may prove the existence of alienation between young researchers and residents of Sandomierz. Nosowski criticized, among others, the lack of an important answer to the question, which Tokarska-Bakir asks her students, what kind of people they met in Sandomierz: good or bad. „The same as we" - falls the first response, which we do not hear in the film. Nosowski also emphasized that in the film there were not any examples of positive actions that took place during the workshop ${ }^{61}$.

\section{Psychoanalytic function of post-Jedwabne art}

According to Joanna Tokarska-Bakir, Polish anti-Semitism demands collective psychoanalysis. She cites, among others, Konstanty Jeleński that in the Parisian "Kultura" in 1957 justified the need with similar regularities, as in the case of patients with individual psychotics. The escape from the problem, the negation of the fact of psychosis, self-cruelty at the time of diagnosis appears. Tokarska-Bakir saw all these trends in the Poles' attitudes to the disclosure of the massacre in Jedwabne. The author points the syndrome of "obsession of innocence" functioning in Polish society, which makes many Poles blame people from the margins of society for the Jedwabne massacre, or express

61 I analyse Żmijewski's film and the debate, using: Polakw szafie Artura Żmijewskiego i obrazy sandomierskie, Fundacja im. Stefana Batorego, Warszawa 2007. The material appeared in the series „Debaty”, and these are the people who took part in the discussion: Anna Bikont, Helena Datner, Joanna Tokarska-Bakir, Konstanty Gebert, Agnieszka Graff, Zbigniew Nosowski, Artur Żmijewski and others. 
empathy for killers for the fact that they had suffered from adequate wrongs the Jews before. Moreover, they defended the myth of Polish-Jewish friendship, whose symbol was idyllic, Mickiewicz's Soplicowo as a paradise land of national identity ${ }^{62}$.

The process of psychotherapy (including the collective one) is triggered in the event of traumatic events that are being denied. For Marian Golki denial is an expression of social oblivion. To do this he uses the term „memory suicide”, which is associated with self-deception. The reason for this type of activity may be all that is unpleasant for consciousness and because of the well-being should be subject to amnesia. The Group is particularly keen to forget the actions that should do and did not do, which causes their trauma of shame ${ }^{63}$. And it is often followed by projection. As Jan Tomasz Gross writes in his book Fear Polish postwar anti-Semitism is a transfer of hatred for the victims, who they did not help during the Holocaust, on the contrary - they took their belongings. As a result, Jew began to function as "pushed to the subconscious, and thus even more troubling, the symbol of that $\sin ^{\text {" } 64}$. Material incentives, however, were only an external manifestation of anti-Semitism. Gross says that the Jew by his own postwar presence reminded Poles that are capable of cruel and unworthy acts. „Without expiation for the wrongs inflicted Jews as neighbors fear remains after the crimes of the occupation" 65 .

The process of working through trauma and the recovery of historical memory related to the Polish attitudes toward Jews took on an art that began to fulfill therapeutic functions. It is worth reaching the interesting concept of Tadeusz Lubelski, who used psychoanalytic categories in relation to the so-called Polish film school at the turn of the $50 \mathrm{~s}$ and $60 \mathrm{~s}$ of $20^{\text {th }}$ century. According to Lubelski the then filmmakers like Andrzej Wajda and Andrzej Munk directed films that became a kind of psychotherapeutic session for the society. As a therapist "who wants to help his patient with reintegration of his personality, rickety, or uncertain of itself, the artist in certain situations tries to restore the health of communities of their recipients, providing them with self-knowledge"66. According to Lubelski then films allowed both to break down taboos (restoring a debate around the themes repressed), as well as disclose complexes (they explained structural weaknesses). I am saying that art commenting massacre in Jedwabne and Polish anti-Semitism fulfilled similar functions.

62 J. Tokarska-Bakir, Rzeczy mgliste..., pp. 19-21.

63 M. Golka, Społeczna niepamięć..., pp. 59-60.

64 J.T. Gross, Strach. Antysemityzm w Polsce tuż po wojnie. Historia moralnej zapaści, Kraków 2008, p. 298.

65 Ibidem, p. 310.

66 T. Lubelski, Strategie autorskie w polskim filmie fabularnym lat 1945-1961, Kraków 2000, p. 139. 
The political significance of art is in this respect that it can be the means by which it is possible to both reveal the contradictions inscribed into the very constitution of the identity of the entity (anti-Semitism as a denial of a coherent identity), as well as proposing imaginary ways to overcome them. Two groups of such methods can be found. The first includes solutions based on ideological closure. Disclosure of the traumatic truth is the beginning of the elimination of injustice, which in turn leads to the regeneration of public order and community self-purification. This solution is clearly visible in the more conventional works, where the spectator has ready-made, consistent answers. As Dariusz Nowacki in the review of fiction book Pingpongista by J. Hen says (indirectly referring to the massacre in Jedwabne): "In the black-and-white tale everything is decided in advance: the evil is condemned, nobility rewarded, negative characters are compromised, and the positive ones triumph"67.

The strategy of ideological closure and the triumph of justice after years can also be very provocative socially and because of this need. Władysław Pasikowski in Pokłosie convinced of that. Thanks to the formula of thriller of the problem of murdering Jews by Poles he managed to enter the fascinating intrigue and translate in a dramaturgically interesting for the ordinary viewer way. At the same time, according to Piotr Forecki it was the movie that played against other officially legitimate stories, where mostly Poles save Jews, shifting deeds of the minority onto the entire community (e.g. W ciemności by Agnieszka Holland) ${ }^{68}$. Paweł Pawlikowski chose another variant of the ideological closure. In Ida he escapes intentionally from the politics ensuring universal moral, humanistic and existential perspective, which however did not prevent him from ideological evaluations and interpretations of critics ${ }^{69}$.

Many artists, especially those creating outside commercial art, designed on the assumption for a wide audience, chose another strategy of approach to the trauma of antiSemitism. This approach relies on uncovering in the process of collective psychotherapy different kinds of slots, where the consistent, fair and closed culmination of the problem is not possible. This group of artists emphasizes not so much the ultimate self-cleaning, but the process of working through, which leads to that. According to Katarzyna Bojarska: „All coherent, orderly and understandable story about the Holocaust is another attempt of pushing deep memory in the depths of the unconsciousness and

67 D. Nowacki, Ogrom stuszności, „Gazeta Wyborcza” on 1 April 2008, p. 16.

68 P. Forecki, Pokłosie, poGrossie i kibice polskości..., pp. 229-232.

69 Such an approach is criticized by Agnieszka Graff and Helena Datner. Taking issue with Krzysztof Varga they acknowledged that no work of art of a Jewish theme is politically innocent, and universalization is only one of the strategies to hide the political dimension. The reception of $I d a$ aesthetics dominates the politics, but in reality political objectives are implemented in order to maintain the stereotypic ideas, among others, about the so-called. Jewish communism. See wider: A. Graff, H. Datner, My, komisarki od kultury, „Gazeta Wyborcza” on 13 November 2013, p. 17. 
covering it under the guise of taming, understandability" 70 . That is why all the gestures are so important by which arrangement of working through the hidden thing is made. In 2002, Wilhelm Sasnal created a mural in BWA Gallery in Bielsko-Biała, where he placed a dialogue in speech bubbles, but without drawings, from one page of comic book Maus by Art Spiegelman. The comic related, among others, to a few glorious actions of Poles towards Jews during World War II (in addition heroes, depending on nationality, are depicted as different animals; Poles are pigs). Critic Adam Ostolski saw in it the transfer of meaning when a personal, true story told in the comic is transformed into a public gesture, and so somehow popularized ${ }^{71}$.

Artists fleeing from ideological closure, from obsequious and tamed version of the fight against anti-Semitism often chose the method of provocation of the spectator. The aim of this action was to work through the trauma of Jedwabne more actively without giving simple solutions, so that justice will triumph. It was an artistic version of „revenge of memory” of which Jacek Żakowski wrote. This syndrome is expressed by the appearance in public debate of events that are indeed known, but have not been discussed yet so they demand social working through ${ }^{72}$. The vast majority of works discussed in the text consists of the complex artistic image of post-memory, understood as ,the structure of the transfer of traumatic knowledge and experience between generations and over them"73. The post-Jedwabne art, understood in such a way, sets at the same time horizon of „post-traumatic culture” because it „focuses around a central trauma, of a long standing and displaced, which unexpectedly comes back and subjects to revision of the entire current reality" 74 . The strategy that helped to realize these objectives was, among others, active drawing the viewer into the reception of work aiming at taking him from a comfortable position of the observer. We see this even in theatrical productions.

In the play Mykwa by Piotr Rowicki, directed by Monika Dobrowlańska, which was played the stage of the Polish Theatre in Poznan, in one of the scenes, we see ordinary people who get up from their seats for the audience and tell the details of the committed murders. The ones they do not feel guilty of and they do not want to remember. An interesting procedure was used in the play Nic co ludzkie. This is a triptych connected with the same theme of crime, directed by three directors: Pawel Passini, Piotr Ratajczak and Łukasz Witt-Michałowski. They met at workshops Laboratorium

70 K. Bojarska, Oni z Sandomierza, Wy z Jedwabnego, My... O „Polaku w szafie” Artura Żmijewskiego i dyskusji w Fundacji Batorego, source: http://www.obieg.pl/1871 [access: 20.04.2015].

71 Wilhelm Sasnal, „Maus”, source: http://culture.pl/pl/dzielo/wilhelm-sasnal-maus [access: 15.05.2015].

72 J. Żakowski, Rewanż pamięci, „Gazeta Wyborcza” 2001, 26-27 May 2001, p. 8.

73 M. Hirsch, Pokolenie postpamięci..., p. 29.

74 J. Tokarska-Bakir, Historia jako fetysz, „Gazeta Wyborcza” on 15 February 2003, p. 20. 
Dramatu with Jan Tomasz Gross to work through his book Fear and Neighbors, and My $z$ Jedwabnego by Anna Bikont. In subsequent scenes, we watch various events from the position of a victim, witnesses and the executioner. The strategy of turning the spectators into the spectacle was particularly interesting. Actors spoke among spectators about Polish manifestations of anti-Semitism during the war (pogroms in Jedwabne and Kielce), and the spectators watched their own reactions on large screens. Kalina Zalewska identified this kind of measures as "a kind of emotional blackmail, although used in good faith to shake consciences" 75 . In Nasza klasa we learn the most irrational acts of cruelty, like the murder and torture, through verbal relationships of characters who turn directly to the audience, to emphasize that certain things can not be shown, that we are always at the mercy of a subjective story. At the same time, however, this type of formula forced the audience to imagine what actually happened. It is the symbolic imaginative sphere, but not the factual one proved to be crucial.

Strategies for the activation of the spectator are also evident in the gallery art. An example would be a project Literatura patriotyczna by Rajkowska (2006). In the Centre for Contemporary Art Ujazdowski Castle in Warsaw the artist arranged a kind of reading room with pleasant light and a big, soft bed, where anti-Semitic books were spread, which can be easily purchased in the capital. Different publications were re-printed in the version of the mirror reflection. Facing such illegible version, the recipients realize that the content, which they do not notice every day, is a collection of nonsense.

Artist Zofia Lipecka suggests thoughtful and complex actions aimed at working through the collective memory in her exhibition Po Jedwabnem, which took place in Zachęta National Gallery of Art (Zachęta Narodowa Galeria Sztuki) in Warsaw in 2008. The content of the video installation of the artist living permanently in France are four projections (two facing each other), infinitely multiplied by mirrors hanging on the other two walls. The viewer sees the installation as if from the inside, as a participant that must confront the problem of the Holocaust. "According to this work, we are the screen, which not-worked-through history throws its image on"76. In the movies, we see people's faces and their reactions to Szmul Wasersztajn's testimony about the pogrom in Jedwabne, which is included in Gross's Neighbours. Izabela Kowalczyk describes such worked-through testimonies as post-testimonies, which are an important part of post-memory. Stressing the processual character of post-memory Kowalczyk uses the term "rememoration" borrowed from the philosopher Paul Ricoeur. This is the denial of memory-repetition and full expression of the critical work on memory of Holocaust witnesses. This is possible due to inscribing testimonies of the Holocaust witnesses in a new, contemporary contexts, and rememorating just the sites of the Holocaust.

75 K. Zalewska, Krajobraz po Grossie, „Teatr” 2008, nr 12, p. 4.

76 I. Kowalczyk, Odpominanie przestrzeni u Zofii Lipeckiej, Atlas Sztuki 63, p. 4. 
In 2013 another exhibition of Lipecka’s works entitled collectively Tam spadła nam zasłona z oczu (There the veil from our eyes fell off) took place in the gallery Atlas Sztuki. Projects then shown did not relate directly to anti-Semitism of Poles, but rather related directly to the remembrance of the Holocaust by its witnesses. The first of the works presented contemporary, quite ordinary train ride from Warsaw to Małkinia, which during the war was the last station before Treblinka. She visualizes thus a direct witness Jankiel Wiernik's testimony. He was deported to Treblinka and described the tragic journey. The second work shows the effect of repeatedly photographed the point of entry to the village of Treblinka, which today appears to be completely normal. In both projects, the author tries to touch the reality of the place and find out whether up-to-date expressing their trauma is possible ${ }^{77}$. Exhibitions of this kind also have significance from the point of view of a more comprehensive knowledge of the collective memory of the group. After all, among the forms of social oblivion, we can find „false memory", which replaces the real memory being a kind of implant, as well as various manifestations of filtering, and so remembering only what is convenient for the specific community ${ }^{78}$. In the context of the discussed issues this false memory makes us negate Polish anti-Semitism, and the filtering is especially evident in the moments when paople emphasize only that Poles saved Jews (most often with compulsory supplement that most of the Righteous Among the Nations are Poles).

While Lipecka tries to make the of process rememoration by strengthening a sense of reality, Igor Ostachowicz chose a completely different strategy in his novel Noc $\dot{z} y w y c h$ trupów. This is a fantastic, grotesque strategy, which breaks with the dominant tradition of martyrdom in Poland and seeks to determine, as Paul Dunin-Wąsowicz says, new frontiers in the story of the Holocaust ${ }^{79}$. Ostachowicz proposed the idea seemingly curious. His rememoration was expressed by literally showing the Jewish victims of the Warsaw ghetto uprising, who as zombies escape to the streets of modern Warsaw. Moreover, they fall in love in Arkadia Shopping Centre and they desire modern gadgets. As Bartosz Staszczyszyn writes „Getting out of the underworld dead Jews are a grotesque echo of the past buried with the layer of oblivion" ${ }^{80}$. According to this critic pop culture turns out to be ideal for this, , which allows demonstrate that our remembrance is always some form, and heroism is only the scheme imposed on the society. By multiplying Ostachowicz highlights it through multiplying citings from pop culture ranging from the title of George Romero's classic horror Night of the Living Dead, and

77 Ibidem, pp. 2-5.

78 M. Golka, Społeczna niepamięć..., pp. 52-53.

79 P. Dunin-Wąsowicz, „Noc żywych Żydów” Igora Ostachowicza w finale Nike, „Gazeta Wyborcza" on 13 September 2013, p. 25.

80 B. Staszczyszyn, Noc żywych Żydów - Igor Ostachowicz, source: http://culture.pl/pl/dzielo/ noc-zywych-zydow-igor-ostachowicz [access: 26.05.2015]. 
ending on borrowings from the movies of Quentin Tarantino. In this way de-naturalizes both oblivion and official memory. Pop culture is a form into which you can put everything, even the historical memory. The importance of Ostachowicz's book lies in the fact that it reveals the shady businesses. The novel met with critical acclaim and was nominated for the prize Nike in 2013, and in 2014 was transferred to the stage of Dramatic Theatre in Warsaw, directed by Marek Kalita.

\section{Bibliography}

„Sięgnałem do komentarzy pod dwoma tekstami. Znalazłem morze agresji”, list Mikołaja Grynberga do redakcji „Gazety Wyborczej”, http://wiadomosci.gazeta.pl/wiadomosci/1,126753,17889872, Siegnalem_do_komentarzy_pod_dwoma_tekstami__Znalazlem.html\#MTstream [access: 17.06.2015].

Antysemityzm jako taki, Przemysław Wiszniewski talks with Halina Bortnowska, http://www. otwarta.org/halina-bortnowska-antysemityzm-jako-taki/ [access: 10.05.2015].

Bartana Y., ... I zadziwi się Europa, Press release prepared and published by the Warsaw Zachęta and signed with the seal of the Jewish Renaissance Movement. The note was issued in connection with the display of the work of Y. Bartany at the International Art Exhibition in Venice in 2011.

Bilewicz M., Marchlewska M., Soral W., Winiewski M., Mowa nienawiści. Raport z badań sondażowych, Warszawa 2014.

Bilewicz M., Soral W., Winiewski M., Antisemitism in Poland 2013: Research Report based on Polish Prejudice Survey II, Warszawa 2013.

Bilewicz M., Wyjaśnianie Jedwabnego: antysemityzm i postrzeganie trudnej przeszłości [in:] Antysemityzm w Polsce i na Ukrainie. Raport zbadań, I. Krzemiński (edit.), Warszawa 2004.

Bojarska K., Oni z Sandomierza, Wy z Jedwabnego, My... O „Polaku w szafie” Artura Żmijewskiego i dyskusji w Fundacji Batorego, http://www.obieg.pl/1871 [access: 20.04.2015].

Ciołkiewicz P., Debata publiczna na temat mordu w Jedwabnem w kontekście przeobrażeń pamięci zbiorowej, „Przegląd Socjologiczny” 2003, nr LII/1.

Čolović I., Polityka symboli. Eseje o antropologii politycznej, Kraków 2001.

Czyżewski M., W stronę teorii dyskursu publicznego [in:] Rytualny chaos. Studium dyskursu publicznego, Kraków 1997.

Diabelskie szczegóły, Jacka Żakowski's converstion with Tomasz Szarota, „Gazeta Wyborcza” on 18-19 November 2000.

Drewniak Ł., Seans nienawiści, źródło: http://www.teatr.bielsko.biala.pl/s/seans-nienawisci.html [access: 21.07.2015].

Dunin-Wąsowicz P., „Noc żywych Żydów” Igora Ostachowicza w finale Nike, „Gazeta Wyborcza” on 13 September 2013.

Dzisiaj omijam zawiść, D. Subbotko's interview with a painter z W. Sasnal, „Gazeta Wyborcza” on. 9 February 2012, Suplement „Duży Format”.

Felis P.T., „Ida” antypolska?, „Gazeta Wyborcza” on 22 January 2015.

Forecki P., Pokłosie, poGrossie i kibice polskości, „Studia Litteraria et Historica” (SLH) 2013, nr 2.

Forecki P., Spór o Jedwabne: analiza debaty publicznej, Poznań 2008.

Golka M., Społeczna niepamięć: pomiędzy zapominaniem a zamazywaniem [in:] Pamięć, przestrzeń, tożsamość, S. Kapralski (edit.), Warszawa 2010.

Graff A., Datner H., My, komisarki od kultury, „Gazeta Wyborcza” on 13 November 2013.

Gross J.T., Strach. Antysemityzm w Polsce tuż po wojnie. Historia moralnej zapaści, Kraków 2008.

Hirsch M., Pokolenie postpamięci, „Didaskalia” 2011, październik, nr 105. 
http://borderlandsofartand.blogspot.com/2014/06/spiewnik-prawdziwego-polaka.html [access: 14.06.2015].

https://www.pisf.pl/rynek-filmowy/rynek-filmowy/widzowie [access: 23.11.2015].

https://www.youtube.com/watch?v=r21Jur404Lo [access: 12.07.2015].

Janion M., Trudna klasa w ciężkiej szkole, preface to: J. Tokarska-Bakir, Rzeczy mgliste. Eseje i studia, Sejny 2004.

Jedlińska E., Rafał Jakubowicz - Synagoga/Ptywalnia, „Pro Memoria”, Biuletyn Informacyjny Państwowego Muzeum Auschwitz-Birkenau Fundacji Pamięci Ofiar Obozu Zagłady AuschwitzBirkenau, 2007, nr 27.

Kaniowska K., „Memoria” i „postpamięć” a antropologiczne badanie wspólnoty [in:] Codzienne i niecodzienne. O wspólnotowości w realiach dzisiejszej Łodzi, G.E. Karpińska (edit.), „Łódzkie Studia Etnograficzne", vol. 43, Łódź 2004.

Karwat M., Polityczność i upolitycznienie. Metodologiczne ramy analizy, „Studia Politologiczne” 2010, Vol. 17.

Klata po protestach $w$ Starym Teatrze: Można przeczytać, że jestem Żydem, pedałem, pornoKlata. Aktorzy dostają listy z pogróżkami, http://m.wiadomosci.gazeta.pl/wiadomosci /1,117915,15015109,Klata_po_protestach_w_Starym_Teatrze__Mozna_przeczytac_html [access: 20.07.2015].

Kosiewski P., Żydzi! Wracajcie!, „Tygodnik Powszechny”, 27 February 2008, http://tygodnik.onet. $\mathrm{pl} /$ zydzi-wracajcie/tnsm5 [access: 15.07.2015].

Kowalczyk I., Odpominanie przestrzeni u Zofii Lipeckiej, Atlas Sztuki 63.

Kowalski S., Tulli M., Zamiast procesu. Raport o mowie nienawiści, Warszawa 2003.

Krzemiński I., Polacy i Żydzi - wizja wzajemnych stosunków, tożsamość narodowa i antysemityzm [in:] Trudne sąsiedztwa. Z socjologii konfliktów narodowościowych, A. Jasińska-Kania (edit.),Warszawa 2001.

Krzemiński I., Postawy antysemickie po dziesięciu latach i ich wyznaczniki [in:] Antysemityzm w Polsce i na Ukrainie. Raport zbadań, I. Krzemiński (edit.), Warszawa 2004.

Kyzioł A., My z naszej klasy, „Polityka”, 30 October 2010, http://www.polityka.pl/tygodnikpolityka/kultura/teatr/1509844,1,recenzja-spektaklu-nasza-klasa-rez-ondrej-spisak.read [access: 14.07.2015].

Lubelski T., Strategie autorskie w polskim filmie fabularnym lat 1945-1961, Kraków 2000.

Malarz tylko psa wymyślit, rozmowa Anny Bikont z Joanną Tokarską-Bakir, „Gazeta Wyborcza” on 22 November 2008.

Melosik Z., Poststrukturalizm jako teoria życia społecznego, „Kultura Współczesna” 1997, nr 1.

Minkner K., Główne problemy konceptualizacji pojęcia polityczności, „Studia Politologiczne” 2015, vol. 37.

Minkner K., O filmach politycznych. Między polityka, politycznościa i ideologią, Warszawa 2012.

Minkner K., Problem polityczności jako metateoretyczne wyzwanie dla politologii, „Athenaeum” 2014, nr 43.

Nowacki D., Robota ilustracyjna i wychowawcza, „Teatr” 2008, nr 12.

Nowacki, Ogrom słuszności, „Gazeta Wyborcza” on 1 April2008.

Odmiany dyskursu politycznego, P. Woroniecki (edit.), Olsztyn 2007.

Ondrej Spišák o „Naszej klasie”, http://teatrdramatyczny.pl/index.php?option=com_conten$\mathrm{t} \& \mathrm{view}=$ article\&id=851:ondrej-spiak-o-qnaszej-klasieq\&catid=65\&Itemid=251 [access: 12.07.2015].

Ostachowicz I., Noc żywych Żydów, Warszawa 2012.

Pipes, Potęga spisku. Wpływ paranoicznego myślenia na dzieje ludzkości, Warszawa 1997.

Płonie stodoła. Na pamiątkę pogromu Żydów, http://www.tvn24.pl/wiadomosci-z-kraju,3/ploniestodola-na-pamiatke-pogromu-zydow,139672.html [access: 16.07.2015].

Polak w szafie Artura Żmijewskiego i obrazy sandomierskie, Warszawa 2007.

Ranciere J., Estetyka jako polityka, Warszawa 2007.

Rubisz L., Polityczność historii. Uwagi teoretyczne i metodologiczne, „Athenaeum” 2014, nr 43. 
Rytualny chaos. Studium dyskursu publicznego, Czyżewski M., Kowalski S., Piotrowski A. (edit.), Kraków 1997.

Sobkowiak L., Świadomość i socjalizacja polityczna [in:] Studia z teorii polityki, t. 1, Jabłoński A.W., Sobkowiak L. (edit.), Wrocław 1999.

Sobolewski T., Światopoglądowe zasieki, „Gazeta Wyborcza” on 14 November 2013.

Staszczyszyn B., Noc żywych Żydów - Igor Ostachowicz, http://culture.pl/pl/dzielo/noc-zywychzydow-igor-ostachowicz [access: 26.05.2015].

Such J., Szcześniak M., Filozofia nauki, Poznań 2000.

Szacka B., Czas przeszły, pamięć, mit, Warszawa 2006.

Ścigaj P., Tożsamość narodowa. Zarys problematyki, Kraków 2012.

Tadeusz Słobodzianek, „Nasza klasa”, http://culture.pl/pl/dzielo/tadeusz-slobodzianek-nasza-klasa [access: 12.12.2015].

Tokarska-Bakir J., Historia jako fetysz, „Gazeta Wyborcza” on 15 February 2003.

Wilhelm Sasnal, „Maus”, http://culture.pl/pl/dzielo/wilhelm-sasnal-maus [access: 15.05.2015].

Zalewska K., Krajobraz po Grossie, „Teatr” 2008, nr 12.

Ziemkiewicz R.A., Jedwabne, czyli zaduch kłamstwa, „Do rzeczy”, 13 lipca 2013, http://dorzeczy. $\mathrm{pl} / \mathrm{id}, 1095 /$ Jedwabne-czyli-zaduch-klamstwa.html [access: 11.07.2015].

Žižek S., Lacan, Warszawa 2008.

Zofia Lipecka „Po Jedwabnem”, http://culture.pl/pl/wydarzenie/zofia-lipecka-po-jedwabnem [access: 12.07.2015].

Żakowski J., Rewanż pamięci, „Gazeta Wyborcza” 2001, 26-27 May 2001.

Żmijewski A., Stosowane sztuki społeczne, „Krytyka Polityczna” 2007, nr 11/12.

Żukowski T., Nowa krytyczna pamięć, http://www.krytykapolityczna.pl/en/ksiazki/ksiazki-pozaseriami/20130710/przekroj-nowa-krytyczna-pamiec [access: 23.07.2015].

\section{Polish contemporary art to the anti-Semitism of Poles and its political significance}

ABSTRACT

This article presents artistic creativity which worked through the problem of Polish anti-Semitism. Almost all discussed works, performances, films, projects appeared after 2000, when Jan Tomasz Gross published his book Neighbors, in which he described the massacre in the village of Jedwabne (1941) launching a public debate about the responsibility of Poles in the Holocaust of the Jews. In the text, I showed as art, which is conventionally called "post-Jedwabne" was part of this debate. Its political status on possibly general level was associated primarily with the revision of conventionalized historical memory and national identity formed on romantic patterns.

The text shows that the debate with the participation of artists formed part of the rules of socalled ritual chaos, so the highly polarized positions, in which anti-Semitism was considered as an obvious and determining such events as the ones in Jedwabne (the opinion was adopted by artists), or it was denied. Even those works that sought to break away from this dichotomy, as Ida by Pawel Pawlikowski were placed secondarily in it as a part of the public debate. In the text, I explained that the post-Jedwabne art worked through primarily so-called secondary anti-Semitism. The political potential of these gestures was related to the disclosure of social antagonisms and tensions arising from the fact that Poles denied phenomenon of their own anti-Semitism and put the blame on the Jews for the fate, which they met. A very important aspect (political as well) also proved the psychotherapeutic function of post-Jedwabne art. In this perspective, events such as the pogrom in Jedwabne appear like trauma, which disintegrates the national identity. Translating it into artistic strategies many artists applied measures that were to deprive the viewer the secure role of an observer in favor of an active, working through participant. 


\title{
Polska sztuka współczesna wobec antysemityzmu Polaków i jej polityczne znaczenie. Przyczynek do analizy dyskursu elit symbolicznych
}

\author{
STRESZCZENIE
}

W artykule przedstawiono kontekstową analizę polskich dzieł sztuki współczesnej (literackich, teatralnych, filmowych, instalacji itp.), które przepracowywały problem polskiego antysemityzmu. W tym celu autor posłużył się zbiorczą etykietą „sztuka postjedwabna” ponieważ jej ilościowy i jakościowy rozwój wiąże się z ukazaniem książki Sąsiedzi Jana Tomasza Grossa, opowiadającej o zbiorowym wymordowaniu Żydów przez Polaków we wsi Jedwabne (1941). Twórczość „postjedwabną” autor postrzega jako część debaty publicznej dotyczącej tego problemu, a samych twórców jako elity symboliczne, które poprzez swoje dokonania pragną kształtować świadomość i rewidować konwencjonalną tożsamość zbiorową Polaków opartą na romantycznych wzorach. W tym też dostrzegać można polityczny potencjał omawianej sztuki.

W tekście wykazano, iż dyskurs artystów dotyczący polskiego antysemityzmu wpisywał się w reguły tzw. rytualnego chaosu, a więc układu silnie spolaryzowanych stanowisk, w ramach którego antysemityzm Polaków uznawano albo jako czynnik determinujący takie wydarzenia jak w Jedwabnem (to stanowisko przyjęli m.in. artyści) albo zupełnie go negowano. Nawet te dzieła, które starały się wyłamywać z tej dychotomii były w nią wpisywane (np. film Ida). W tekście przedstawiono nie tylko analizę samych dzieł, ale również ich interpretacji. 